\title{
Evaluation of Materials Suitable for Use in Eddy Currents Non-Contact Brakes Disc in Automobile Application
}

\author{
Munyaradzi Innocent Mupona ${ }^{1}$, Ranjeet Singh Tomar ${ }^{2}$ \\ ${ }^{1}$ ITM University, Department of Mechanical Engineering, \\ NH-75, Jhansi Road, Gwalior, Madhya Pradesh, India \\ ${ }^{2}$ ITM University, School of Engineering and Technology, \\ NH-75, Jhansi Road, Gwalior, Madhya Pradesh, India
}

\begin{abstract}
Due to the advancement in technology and desire to provide motor vehicles that are lightweight, fuel efficient, environmentally friendly and economical, designers are now faced with innovative challenge to keep up the technological advancements in all aspects of motor vehicle design. This paper focuses on the evaluation of material to use for the brake disc design of a non-contact braking system for light weight motor vehicles while optimizing on braking efficiency and minimizing vehicle maintenance cost. The author made use of the available researches prior to the study so as to come up with the best material which can be used to make the application of this technology a success in light motor vehicles. After a detailed evaluation of the available materials, whilst looking at a multiplicity of factors such as cost, manufacturability, durability, environmental friendliness and applicability, aluminum was found to be the most suitable material for the application.
\end{abstract}

Keywords: Material, Non-contact brakes, Light weight motor vehicles, Brake disc, Environmental friendly

\section{Introduction}

There is a paradigm shift in the automotive sector where vehicles have been evolving over the past decades at a fast rate. Considering all the systems on vehicles, one that has had some of the slowest development and upgrade rate has been the braking system. It can be seen that most vehicles on the roads still use mechanical and hydraulic breaking system that dates back to the late 19th century. The system has clearly proved its longevity but it comes with its own set of problems, which include heavy weight, cumbersome installation, low energy efficiency and requires regular maintenance.

Another major problem with the current braking system is its reliance on converting kinetic energy of the vehicle to mainly heat energy, this method of braking is achieved through friction which is the chief cause of the wear and need for regular maintenance and above all, these brakes can lose effectiveness due to overheating in a stressful scenario. With the demand for vehicle weight reduction, improved fuel efficiency and environmentally friendly vehicles, all countering, it is important that braking systems are developed to meet these challenges. In light of all these a disadvantages of the current systems, a paradigm shift can be brought to the braking systems of vehicles by eliminating the frictional aspect as this will inevitably take away the reliance of the system's reliability on the driving habits of the operator and the working conditions that the system is subjected to. In the current braking technology, it can be noted that the most efficient braking systems always come at a premium mainly due to the special materials needed to make them e.g. carbon ceramic brake discs

\section{Literature Survey}

A number of researches and experiments have been done so as to determine the feasibility and optimal operating conditions of the eddy current non-contact braking systems in various applications. Although the technology is not being commonly used in light weight motor vehicles it has been successfully implemented in locomotive engineering and heavy vehicles where it is commonly used in conjunction with the frictional braking systems. The eddy currents brakes are mainly used for speed retardation purposes since they have not proved their efficiency at low speeds.

\subsection{Operating principle of eddy-current brakes}

Eddy current brakes are part of the science of electromagnetism, electricity and magnetism are not two separate entities but they go hand in hand. Michel Faraday and Joseph Henry in 1831 discovered that relative motion between a magnetic field and a conductor induces an electromotive force in the conductor, causing a current to flow in the conductor and thus the eddy-currents. Heinrich Lenz in 1834 stated the principle that defines the properties of the induced current which state that "the current induced in a circuit due to a change or a motion in a magnetic field is so directed as to oppose the change in flux and to exert a mechanical force opposing the motion"[1].

Eddy current brakes are categorized into two forms which are linear and circular brakes; they both have one static part and one moving part. The circular eddy-currents brakes come in two main kinds, according to whether the electromagnet is in motion or fixed. The most common designs operate in the same manner as the frictional brakes, with a static 


\section{International Journal of Science and Research (IJSR) \\ ISSN (Online): 2319-7064 \\ Index Copernicus Value (2013): 6.14 | Impact Factor (2014): 5.611}

electromagnet and a rotating disk which cuts through the magnetic field. As the metal disk cuts through the magnetic field a current which moves in a circular manner in the disk is created thus the eddy currents, according to Lenz law the induced current will create its own magnetic field that opposes the magnetic field that created it there by providing the necessary drag force required to retarding the motion of the disk [2]-[4].

On the other design a series of electromagnets are mounted on an outer wheel that spins around a fixed central shaft, as the magnetic field is the one in motion eddy currents are induced in the shaft and using the same principle a drag force is created causing a reduction in motion. This is the common design mainly used on many trucks, buses, and coaches, called the Telma frictionless retarder [2]-[4].

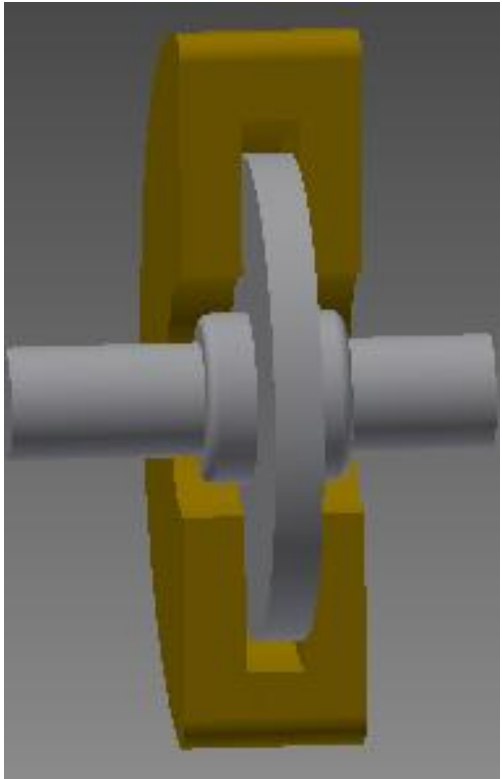

Figure 1: Non-contact eddy current braking system

\subsection{Impact of rotor disc material}

The proper selection of rotor disc material is very important in the design of eddy current brakes. Eddy current brakes rely on various material properties hence a material with good mechanical properties, a high electrical conductivity and good power dissipation capabilities.

Ferromagnetic materials display poor performance characteristics in the use as eddy currents disc materials. There are three strong candidates of material which are zinc, copper and aluminum. Baharom et al. investigated these materials in order to determine a more suitable material .From their experimental evaluation aluminum proved to be the best material. A further investigation was carried out to analyze two different alloys of aluminum which are Al6061 and Al7075, from the study was concluded that Al6061 has greater performance than Al7075 as the brake disc material [5], [6]. The ability of aluminum to perform better than the other material is due to the absence of magnetic susceptibility as shown in table (1-3). Although the disc material is not the only parameter to be considered to achieve the optimal results it can be concluded that the disc material plays a pivotal role in obtaining the optimal solution.
Table 1: Properties of Aluminium

\begin{tabular}{|c|c|}
\hline Physical Properties & \\
\hline Density & $2.70 \mathrm{~g} / \mathrm{cc}$ \\
\hline Mechanical Properties & 30 \\
\hline Hardness, Brinell & $124 \mathrm{Mpa}$ \\
\hline Tensile strength Ultimate & \\
\hline Electrical Properties & $0.00000366 \mathrm{ohm}-\mathrm{cm}$ \\
\hline Electrical Resistivity & \\
\hline Thermal Properties & $0.896 \mathrm{~J} / \mathrm{g}-{ }^{\circ} \mathrm{C}$ \\
\hline Specific Heat Capacity & $80 \mathrm{~W} / \mathrm{m}-]$ \\
\hline Thermal Conductivity & $582-651.7^{\circ} \mathrm{C}$ \\
\hline Melting Point &
\end{tabular}

Table 2: Properties of Cooper

\begin{tabular}{|c|c|}
\hline Physical Properties & \\
\hline Density & $8.93 \mathrm{~g} / \mathrm{cc}$ \\
\hline Mechanical Properties & 100 \\
\hline Hardness, Vickers & $220 \mathrm{Mpa}$ \\
\hline Tensile strength Ultimate & \\
\hline Electrical Properties & $0.00000170 \mathrm{ohm}-\mathrm{cm}$ \\
\hline Electrical Resistivity & $-8.00 \mathrm{e}-8$ \\
\hline Magnetic Susceptibility & \\
\hline Thermal Properties & $0.385 \mathrm{~J} / \mathrm{g}-{ }^{\circ} \mathrm{C}$ \\
\hline Specific Heat Capacity & $398 \mathrm{~W} / \mathrm{m}-\mathrm{K}$ \\
\hline Thermal Conductivity & $1083.2-1083.6^{\circ} \mathrm{C}$ \\
\hline Melting Point &
\end{tabular}

Table 3: Properties of Zinc

\begin{tabular}{|c|c|}
\hline Physical Properties & \\
\hline Density & $7.10 \mathrm{~g} / \mathrm{cc}$ \\
\hline Mechanical Properties & \\
\hline Hardness, Vickers & 30 \\
\hline Tensile strength Ultimate & $240 \mathrm{Mpa}$ \\
\hline Electrical Properties & \\
\hline Electrical Resistivity & $0.0000005916 \mathrm{ohm}-\mathrm{cm}$ \\
\hline Magnetic Susceptibility & $-1.74 \mathrm{e}-7$ \\
\hline Thermal Properties & \\
\hline Specific Heat Capacity & $0.3898 \mathrm{~J} / \mathrm{g}-{ }^{\circ} \mathrm{C}$ \\
\hline Thermal Conductivity & $112.2 \mathrm{~W} / \mathrm{m}-\mathrm{K}$ \\
\hline Melting Point & $419.59{ }^{\circ} \mathrm{C}$ \\
\hline
\end{tabular}

\section{Environmental Impact Analysis}

This section presents a comparison of the different materials that can be used for non-contact brake disk. A critical analysis will be conducted between zinc, copper and aluminum, whilst assessing their effect to humans and the environment in general.

\subsection{Aluminum}

Aluminum is one of the mostly abundant elements in the Earth's crust and its compounds occur naturally in our food. High exposure to aluminium can have serious health implications in human. Reactive $\mathrm{Al} 3(\mathrm{aq}+)$ can instigate the inflammatory reaction which can be observed by the reddening and swelling of the skin. The presence of high content of aluminium in a human body can inhibit the functionality of enzymes and more energy will be needed to deal with the physiological response to the presence of aluminum. However the human body has functional mechanism to remove excessive aluminium, or basics

\section{Volume 5 Issue 4, April 2016}




\section{International Journal of Science and Research (IJSR) \\ ISSN (Online): 2319-7064 \\ Index Copernicus Value (2013): 6.14 | Impact Factor (2014): 5.611}

remedies such as consumption of silicon rich mineral water. Although the ability of a human body to react to presence of aluminum can be affected by factors such as ageing or genetics which can result in having aluminium content more than the threshold value [7].

High concentrations of aluminium have adverse effects to some aquatic organism. Dissolved and precipitated aluminium contribute to toxicity in the water, however the amount of aluminum contamination in water has to be localized so as to observe adverse effect. Aluminium contamination will result in low population growth rate and the overall health of the aquatic organisms' habitant in that localized area. Hence proper disposal of aluminum metal or recycling of the material will alleviate the problem of increase in the concentration of aluminum in localized areas [8].

\subsection{Copper}

Copper is a naturally occurring element which means humans would be exposed to copper through inhalation, eating copper contaminated food and drinking copper contaminated water. Copper is essential for good human health, but excess amount of copper can be toxic above. Mild symptoms, such as nausea, vomiting, and abdominal pain can be observed in humans due to excess copper. When a person is exposed to copper levels above the critical levels needed for good health, the liver and kidneys produce a protein called metallothionein which can help the excrete the excess amount [9].

Aquatic organisms require copper at low concentration, but on condition the concentration rise above acceptable level that can result in intoxication of aquatic organisms. Chronic exposure to high concentration of copper can lead to serious effect such as death, reduced reproduction, slow growth rate as well as changes of brain function, metabolism, enzyme activity, and blood chemistry. Dissolved copper is one of the most prevalent source or coper in storm runoff and fresh water sources, however storm water runoff does not usually carry lethal concentrations of copper. Continuous exposure to sub lethal concentrations of copper has been proved to alter the behavior in various species in freshwater, hence proper disposal of copper or recycling of copper can go a long way in protecting the aquatic organisms [10].

\subsection{Zinc}

Zinc and its compounds constitutes of the material found on earth's crust and are present in most rocks, certain minerals, and some carbonate sediments. It is released to the environment from both natural and anthropogenic sources, however releases from anthropogenic sources are greater than those from natural sources. Human beings can be exposed to zinc through inhalation, skin contact and ingestion. Skin contact with zinc powder can result in severe corrosive effects, ulceration, blistering, permanent scarring and ingestion of large quantities of zinc or absorption of more than $225 \mathrm{mg}$ of zinc in a day can result in severe injury to the throat, mouth and stomach. Complications may include gastrointestinal hemorrhage and acute pancreatitis.
However zinc is very useful in a number of biological systems such as biochemical processes that support life and required for a host of physiological functions [11].

Zinc from the earth crust is considered to be very low and unlikely to elevate aquatic concentrations significantly as compared approximately 681,000 metric tonnes per year released into the oceans from high temperature hydrothermal fluids in mid-ocean ridges (WHO 2001). The free zinc ion in solution is highly toxic to bacteria, plants, invertebrates, and even vertebrate fish in fresh waters and localized areas where mining activities are carried out. Excessive absorption of zinc can suppress copper and iron uptake which are essential element for plant and fresh water organisms' growth [12].

\section{Cost benefit analysis}

According to quandl.com of the three materials copper is the most expensive raw material costing about Rs 316.60 per kilogram followed by zinc which is currently priced at Rs 105.65 per kilogram and aluminium is the one which have the least price costing Rs 100.30 per kilogram This makes aluminum the material of choice if purchasing price is considered alone.

A comparisons between the three material show that aluminium and its alloys can easily be machined using most conventional machining methods such as milling, drilling, cutting, punching and the amount of energy input during machining is lower than that of copper and zinc. This is attributed to the low hardness of aluminium as shown in table 1. Low hardness implies that less energy is required while the tool life is extended and that will go a long way in reducing the cost of machining aluminium to copper and zinc. However zinc and copper can also be machined using the conventional methods at a slightly higher cost than aluminium [13].

Of the three materials zinc is the cheapest to perform joining process as it can be welded using conventional welding processes such as preferred arc welding, resistance welding, and gas welding although all the welding process should be done under controlled environment during the entire welding process. For zinc soldering is the most recommended joining process. However aluminium can be easily welded by the incorporation of features into the profile design. Fusion welding, friction stir welding, bonding and taping are also used for joining aluminium and these welding processes require much expertise. Copper can be joined easily by soldering or brazing, and these forms of joining process will not provide a strong joint that can be used critical components such as brake discs [13].

\section{Conclusion}

From the study it can be concluded that aluminium is the best material to use as eddy currents brake disc material, aluminium disc display an increase in braking torque whilst using low current. Furthermore as shown in tables (1-3) aluminium disc have a low density better than copper and 


\section{International Journal of Science and Research (IJSR) \\ ISSN (Online): 2319-7064}

Index Copernicus Value (2013): 6.14 | Impact Factor (2014): 5.611

zinc which means the braking system will be of light weight. Aluminium is the least priced of all the three materials and the cheapest to machine and join hence this will contribute in reducing the cost of the braking system. All metals have proved to be harmful to the environment and humans' hence proper handling and disposal will be required so as to minimize the risk.

\section{References}

[1] Krawczyk, A. and Wiak, S,2002. Electromagnetic Fields in Electrical Engineering. Netherlands: IOS Press.

[2] Puttewar, A ,S., Kakde , N, U., Fidvi ,H , A. and Nandeshwar, B .(2014). Enhancement of Braking System in Automobile Using Electromagnetic Braking, Journal of Mechanical and Civil Engineering, e-ISSN: 2278-1684, PP 54-59

[3] Sevvel, P., Nirmal Kannan ,V .and Mars Mukesh ,S.(2014).Innovative Electro Magnetic Braking System. International Journal of Innovative Research in Science, Engineering and Technology. Volume 3, Special Issue 2,PP 46-53

[4] Patel,S, Patel.,A, Patel.,M, Sanghani.,C and Patel., D .(2015) .Development of the Electro-Magnetic Brake. International Journal for Innovative Research in Science \& Technology. Volume 1, Issue 12, May ISSN (online): 2349-6010

[5] Baharom, M, Z., Nuawi, M, Z., Priyandoko, G., Harris, S, M .and Siow, L,M..(2011). Eddy current braking study for brake disc of aluminum, copper and zinc. Regional Engineering Postgraduate Conference.

[6] Baharom, M., Nuawi, M., Priyandoko, G. and Harris, S. (2012). Eddy current braking experiment using brake disc from aluminium series of A16061 and A17075. IOP Conf. Ser.: Mater. Sci. Eng., 36, p.012005.

[7] Exley, C. (2016). The toxicity of aluminium in humans. Morphologie.

[8] Gillmore, M., Golding, L., Angel, B., Adams, M. and Jolley, D. (2016). Toxicity of dissolved and precipitated aluminium to marine diatoms. Aquatic Toxicology, 174, pp.82-91.

[9] Platten, W., Sylvest, N., Warren, C., Arambewela, M., Harmon, S., Bradham, K., Rogers, K., Thomas, T. and Luxton, T. (2016). Estimating dermal transfer of copper particles from the surfaces of pressure-treated lumber and implications for exposure. Science of The Total Environment, 548-549, pp.441-449.

[10] Sommers, F., Mudrock, E., Labenia, J. and Baldwin, D. (2016). Effects of salinity on olfactory toxicity and behavioral responses of juvenile salmonids from copper. Aquatic Toxicology, 175, pp.260-268.

[11] Nriagu,J.(2007).Zinc Toxicity in Humans. Elsevier

[12] Weiling, Z., Lin, Y., Xuancheng, X. and Shuchun, G. (1991). Toxic effects of zinc on four species of freshwater fish. Chin. J. Ocean. Limnol., 9(1), pp.64-70.

[13] Karwa, R., 2006. machine desing. second ed. New Delhi: Laxmi Publications.

\section{Author Profile}

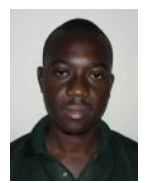

Munyaradzi Innocent Mupona is pursuing a Post Graduate degree in M.Tech Machine Design at (Institute of Technology and Management) I.T.M University, Gwalior, M.P, India., he is a holder of a B.Tech Honors Degree in Industrial and Manufacturing Engineering from Harare Institute of Technology, Zimbabwe which was awarded in 2012.In 2014 he was awarded a certificate of accomplishment in introduction to environmental law and policy from University of North Carolina at Chapel hill's open online course.

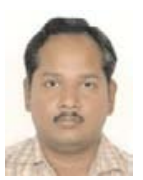

Ranjeet Singh Tomar is pursuing Ph.D. from Indian Institute of Information Technology, Allahabad, India in Information and Communication Technology. $\mathrm{He}$ received his M. Tech. degree from MNIT, Jaipur, India. His research interest areas are Wireless Networks and Communication, Wireless Sensor Networks, Digital \& Mobile Communication, Signal Processing and VANETs. 